\title{
The knowledge of selected cancer prevention methods among Polish outpatients
}

\author{
MARTA KURCZEWSKA-MICHALAK ${ }^{A-F}$, PRZEMYSŁAW KARDAS ${ }^{A}, \mathrm{D}, \mathrm{E}, \mathrm{G}$ \\ Department of Family Medicine, Medical University of Lodz, Poland
}

A - Study Design, B - Data Collection, C - Statistical Analysis, D - Data Interpretation, E - Manuscript Preparation, F - Literature Search, G - Funds Collection

Summary Background. Most prevalent cancers are, in their majority, not fully preventable. However, early diagnosis dramatically increases the chances for effective treatment and positive prognosis. Unfortunately, patients' participation in relevant screening activities is far from desirable. Taking into consideration the increasing incidence of cancer and mortality in Poland, a higher uptake of these programs is advisable.

Objectives. The purpose of this study was to assess the knowledge of selected cancer prevention methods among Polish outpatients. Material and methods. This was a survey involving Polish primary care patients. The study was based on an original questionnaire designed for this purpose and was distributed among primary care patients in either hardcopy (among primary care patients in the urban settings of the city of Lodz) or over the Internet.

Results. Sources of information on national cancer screening programs provided by the survey participants significantly correlated with gender, age and education level. Women tended to be significantly more interested in current or future participation in the colorectal screening program than men $(46.7 \%$ vs $32.3 \% ; p<0.05)$. The majority of women were well informed about screening tests concerning breast and cervical cancer (78.2\%). The period of time between cervical cancer screenings significantly correlated with the level of education $(p<0.05)$.

Conclusions. 1. Television and press are the most common sources of information regarding national cancer screening programs. 2. Women were more interested in participation in colorectal screening than men. 3. Lack of availability of screening tests proved to be the most common reason for delay in cancer diagnosis provided by respondents.

Key words: cancer, screening tests, prevention programs.

Kurczewska-Michalak M, Kardas P. The knowledge of selected cancer prevention methods among Polish outpatients. Fam Med Prim Care Rev 2017; 19(3): 235-238, doi: https://doi.org/10.5114/fmpcr.2017.69283.

\section{Background}

Malignant tumours have become the greatest challenge for worldwide medicine in recent years. Therefore, effective cancer prevention is of the utmost importance. Unfortunately, not all cancers are preventable via currently available methods, and thus, secondary prevention of cancers, based on the identification and treatment of premalignant or subclinical cancers, is a must.

All over the world, as well as in Poland, there are several well-organised and recommended cancer screening programs. The targets for these population-based preventive activities are defined according to the prevalence of different types of cancers, as well as the availability of safe and effective preventive methods. According to the Globocan database, breast cancer ranks first among women and second in the overall population worldwide, including Poland. Colorectal cancer seems to rank second among women and third among men, both in the world and in Poland [1, 2]. Cervical cancer is the second most common cancer in women aged $15-39$ years [3]. On average, over $60 \%$ of women in Europe are alive five years after the diagnosis of cervical cancer [4]. Survival rates, however, vary and are low in several European countries, including Poland [5].

Persistent infection with a high-risk human papillomavirus (HPV) genotype is required for the development of high-grade cervical neoplasia (cervical intraepithelial neoplasia [CIN] grade 3, adenocarcinoma in-situ, and invasive cervical cancer $(\mathrm{CIN} 3+))[6]$. There are more than 100 types of HPV, of which at least 13 are cancer causing (also known as high-risk type).
Two HPV types (16 and 18) cause $70 \%$ of cervical cancers and precancerous cervical lesions. Although most HPV infections clear up on their own, and most pre-cancerous lesions resolve spontaneously, there is a risk for all women that HPV infection may become chronic, and pre-cancerous lesions can progress to invasive cervical cancer. It takes 15 to 20 years for cervical cancer to develop in women with normal immune systems. It can take only 5 to 10 years in women with weakened immune systems, such as those with untreated HIV infection [7]. Similarly to cervical cancer, it can take as many as 10 to 15 years for a polyp to develop into colorectal cancer. Regular screening can often prevent colorectal cancer by finding and removing polyps before they have the chance to turn into cancer. Screening can also often find colorectal cancer early, when it is most likely to be curable [8].

Early diagnosis of breast cancer generally increases the chances for successful treatment by focusing on detecting symptomatic patients as early as possible. Delays in accessing cancer care are common with late-stage presentation, particularly in lower resource settings and vulnerable populations. The consequences of delayed or inaccessible cancer care are a lower likelihood of survival, greater morbidity of treatment and higher costs of care, resulting in avoidable deaths and disability from cancer. Early diagnosis improves cancer outcomes by providing care at the earliest possible stage and is therefore an important public health strategy in all settings [7].

These three cancers can be effectively screened by means of mammography, a cervical screening test and colonoscopy, re- 
spectively. However, despite their availability for free within the national healthcare system, all these tests are currently underused in Poland. Considering the increasing incidence of cancer and mortality in Poland [2], a better uptake of national cancer prevention programs is advisable. Primary care doctors may play an important role in raising awareness of, and building motivation to undergo, these screening activities, thus helping early and rapid diagnosis of major oncological conditions. The first, and also the only, contact a patient has with national healthcare services is very often restricted to primary healthcare. Therefore, a GP's particular position in the national healthcare system obligates him/her to spread information about cancer prevention among their patients [9]. GPs should undertake activities connected with primary cancer prevention (information about behaviours, exposure and other factors that may influence the risk of cancer), as well as secondary prevention of cancer (early detection during a routine physical examination and promotion of screening) [10].

\section{Objectives}

The purpose of this study was to assess the knowledge of selected cancer prevention methods among Polish outpatients. Our aim was also to determine the factors responsible for reluctance to participate in national cancer prevention programs and those connected with delay in diagnosis and treatment. Furthermore, we wanted to determine which of the available sources of information on cancer prevention programs are the most important for patients.

\section{Material and methods}

This was an open study involving primary care patients and an Internet-based survey. The study was based on an original questionnaire designed for this purpose, distributed among primary care patients in the urban settings of Lodz, Poland, and made available on a dedicated web site for the respondents from Poland. Patients at least 18 years of age who voluntarily agreed to participate in the study were eligible for the research. The questionnaire consisted of 40 questions, of which 10 were open questions, and the remaining were multiple-choice questions. Quantitative data was analysed using SPSS, employing descriptive and non-parametric statistics. The Shapiro-Wilk test was employed to assess normality of distribution. Data was analysed using the chi-squared test and Mann-Withney test, wherever applicable. A $p$-value of $<0.05$ was considered significant.

\section{Results}

Patients' characteristics are provided in Table 1. Among 612 respondents who took part in the study, women amounted to nearly $2 / 3(56.9 \%)$ of the total. Most of the respondents had university education (64.7\%); most of the answers came from those aged 25-49 (50.7\%).

\begin{tabular}{|l|l|l|}
\hline \multicolumn{3}{|l|}{ Table 1. Characteristics of the survey participants } \\
\hline Variable & $n$ & percentage [\%] \\
\hline Gender & & \\
male & 215 & 35.1 \\
female & 348 & 56.9 \\
missing data & 49 & 8.0 \\
\hline Age & & \\
18-24 & 21 & 3.4 \\
$25-49$ & 310 & 50.7 \\
$50-69$ & 202 & 33.0 \\
missing data & 79 & 12.9 \\
\hline Education & & \\
primary & 4 & 0.6 \\
secondary & 143 & 23.4 \\
university & 396 & 64.7 \\
missing data & 69 & 11.3 \\
\hline Smoking status & & \\
smoker & 119 & 19.4 \\
non-smoker & 423 & 69.1 \\
missing data & 70 & 11.5 \\
\hline Cancer family history & & \\
yes & 329 & 53.8 \\
no & 191 & 31.2 \\
missing data & 92 & 15.0 \\
\hline Vc Total & 612 & 100.0 \\
\hline
\end{tabular}

National cancer prevention programs were well known to $72.8 \%$ of the respondents ( $n=560)$, without any statistically significant difference between men and women. Awareness of the existence of such programs was the greatest among the oldest group, i.e. among respondents aged 50-69 (83.1\%), and lowest among the youngest respondents (those aged 18-24, 61.9\%; $p<0.01$; $n=531)$. Television and the press seemed to be the major sources of information ( $25.8 \%$ and $15.8 \%$, respectively; $n=563$ ); however, radio was more often pointed out by men, whereas women more frequently read leaflets $(p<0.05)$. General practitioners were regarded as a source of information by only $3.6 \%$ of respondents. Press was treated as a source of information by $24.8 \%$ of the oldest group of the respondents; however, among the youngest patients, only $9.5 \%$ had a similar opinion. Leaflets were reported by as many as $33.3 \%$ of the respondents aged $18-24$ (Table 2).

Colonoscopy as a prevention program proved to be known to $56.8 \%$ of all respondents and to as many as $79.1 \%$ of those aged 50-69. There was no significant difference between males and females, taking into consideration the total population. The intention to undergo a prophylactic bowel examination was declared by $41.6 \%$ of the total population, and women tended to be significantly more interested in current or future participation in the program $(46.7 \%$ vs $32.3 \% ; p<0.05)$.

\begin{tabular}{|c|c|c|c|c|c|c|c|c|c|c|}
\hline \multirow{2}{*}{$\begin{array}{l}\text { National cancer screening pro- } \\
\text { grams - information sources }\end{array}$} & \multicolumn{2}{|c|}{ Gender } & \multirow[t]{2}{*}{$p$} & \multicolumn{3}{|l|}{ Age } & \multirow[t]{2}{*}{$p$} & \multicolumn{2}{|c|}{ Education* } & \multirow[t]{2}{*}{$p$} \\
\hline & $M$ & $F$ & & $18-24$ & $25-49$ & $50-69$ & & $\operatorname{Sec}$ & Univ & \\
\hline Press & $\mid 14.0$ & 17,0 & $\mid 0.34$ & 9.5 & 10 & 24.8 & $<0.05$ & 15.4 & \begin{tabular}{|l|}
15.4 \\
\end{tabular} & 0.99 \\
\hline Television & 28.4 & 24,1 & 0.28 & 9.5 & 25.5 & 27.2 & 0.32 & 35 & 21.7 & $<0.05$ \\
\hline Radio & 6.5 & 2,9 & 0.04 & 4.8 & 3.5 & 5.9 & 0.51 & 7.7 & 3.0 & $<0.05$ \\
\hline GP & 2.7 & 4.0 & 0.44 & - & 2.3 & 5.4 & 0.22 & 6.3 & 2.3 & $<0.05$ \\
\hline Leaflet & 10.7 & 17.8 & 0.02 & 33.3 & 12.9 & 17.8 & 0.02 & 20.3 & 13.6 & 0.06 \\
\hline Other sources & 14.4 & 15.5 & 0.72 & - & 17.7 & 13.9 & 0.13 & 9.8 & 17.4 & 0.03 \\
\hline Hard to say & 5.1 & 2.6 & \begin{tabular}{|l|}
0.11 \\
\end{tabular} & 9.5 & 3.5 & 2.5 & 0.55 & 6.3 & 2.8 & 0.05 \\
\hline
\end{tabular}

$\mathrm{M}$ - male, F-female, GP - general practitioner, Sec - secondary education, Univ - university degree; ${ }^{*}$ - due to the low number of respondents with primary education $(n=4)$, they were not used for these statistics. 


\begin{tabular}{|c|c|c|c|c|c|c|}
\hline \multirow{3}{*}{$\begin{array}{l}\text { Period of time from the last screen- } \\
\text { ing test }\end{array}$} & \multicolumn{5}{|c|}{ Cervical cancer } & \multirow[t]{3}{*}{$p$} \\
\hline & \multicolumn{2}{|l|}{ Education* } & \multirow[t]{2}{*}{$p$} & \multicolumn{2}{|c|}{ Family history of cancer } & \\
\hline & secondary & university & & positive & negative & \\
\hline 1-12 months prior & 47.2 & 52.2 & \multirow{6}{*}{0.04} & 56.3 & 54.4 & \multirow{6}{*}{0.29} \\
\hline 13-24 months prior & 21.8 & 26.6 & & 24.6 & 30.4 & \\
\hline $3-5$ years prior & 13.8 & 5.7 & & 9.4 & 3.3 & \\
\hline More than 5 years prior & 4.6 & 3.3 & & 2.7 & 4.4 & \\
\hline Never & 10.3 & 4.1 & & 5.4 & 5.4 & \\
\hline Hard to say & 2.3 & 2.1 & & 1.8 & 2.2 & \\
\hline
\end{tabular}

* - due to the low number of respondents with primary education $(n=4)$, they were not used for these statistics.

The majority of women were well informed about screening tests concerning breast and cervical cancer (78.2\%). Nevertheless, nearly one-fifth of the female respondents (19.4\%) claimed not to have heard of these tests at all. The period of time between cervical screenings significantly correlated with the level of education $(p<0.05)$. Women with a university degree, contrary to those with secondary education, mostly performed the test during the previous year $(58.2 \%$ vs $47.2 \%$, respectively) or past two years (26.6\% vs $21.8 \%$, respectively). Among the women with secondary education, there was still a considerable group which underwent the screening $3-5$ years prior (13.8\%), more than 5 years prior (4.6\%) or never (10.3\%). On the other hand, we did not notice such a correlation between the level of education and the last mammography. Regardless of the education level, over $80 \%$ of female respondents participated in a breast cancer screening. A family history of cancer also seemed not to have a significant influence on participating in breast and cervical screening tests (Table 3 ).

Several important reasons for delay in diagnosis and treatment of cancer were reported by the respondents. Lack of availability of screening tests was mentioned by roughly $50 \%$ of the patients. Secondly, more than one-fourth $(25.6 \%)$ of the male respondents claimed that patients ignore early warning signs, while only $17.5 \%$ of women were of the same opinion $(p<0.05)$ (Table 4).

\begin{tabular}{|l|l|l|l|}
\hline \multicolumn{3}{|l|}{ Table 4. Reasons for delay in cancer diagnosis according to } \\
respondents & \multicolumn{2}{|l|}{ Gender } \\
\cline { 2 - 3 } & $\begin{array}{l}\text { Male } \\
(n=215)\end{array}$ & $\begin{array}{l}\text { Female } \\
(n=348)\end{array}$ & \\
\cline { 2 - 3 } & $\%$ & $\%$ & \\
\hline $\begin{array}{l}\text { Reasons } \\
\text { tests of availability of screening }\end{array}$ & 50.2 & 48.9 & 0.75 \\
\hline $\begin{array}{l}\text { Low awareness of the society, } \\
\text { lack of knowledge }\end{array}$ & 15.8 & 11.2 & 0.11 \\
\hline Lack of early warning signs & 7.9 & 6.6 & 0.56 \\
\hline $\begin{array}{l}\text { Patients ignore early warning } \\
\text { signs }\end{array}$ & 25.6 & 17.5 & 0.02 \\
\hline $\begin{array}{l}\text { General practitioner ignores } \\
\text { early signs }\end{array}$ & 4.7 & 4.9 & 0.89 \\
\hline $\begin{array}{l}\text { Difficult access to specialists and } \\
\text { specialized tests }\end{array}$ & 16.3 & 12.6 & 0.23 \\
\hline
\end{tabular}

\section{Discussion}

Screening still remains the most effective and irreplaceable method of cancer prevention. Nevertheless, to be effective, it has to cover $70-75 \%$ of the target population according to WHO and European Commission recommendations [7]. When consider- ing colorectal cancer, the U.S. Preventive Services Task Force recommends starting screening at the age of 50 years and to repeat every 10 years until the age of 75 [11], Currently, in Poland, the invitation for a prophylactic colonoscopy is sent out once in lifetime to people aged 50-65. A cervical cancer screening is recommended by USPSTF to women aged 21 to 65 every 3 years, while in Poland, to women aged 25-59. USPSTF recommends a mammography to women aged 50-74, whereas in Poland, those aged 50-69 years are covered by the nationwide screening [11]. Despite the increasing number of women responding to invitations, the percentage of women participating in cervical screening in Poland was only $26.7 \%$ in 2009 , with a further decrease to $23.4 \%$ in 2012 and a moderate increase to $42.1 \%$ in 2015 [12]. For comparison, in successful English cervical screening programme the percentage of eligible women (aged 25 to 64) who were recorded as screened adequately at least once in the previous 5 years (five year coverage) was $77.8 \%$ in 2014 and 80.6 in 2004 [13].

In our study, the respondents claim that the role of general practitioners in providing information about cancer screening programs was rather limited. To the contrary, a recent British study proved that the provision of cervical screening services to women is largely a routine procedure, with $95.3 \%$ of GP respondents promoting it. The majority of GPs $(55.3 \%)$ also routinely promoted active screening for cancers other than cervical cancers [14]. Stefanowicz et al., in their study, asked general practitioners about the role of primary healthcare in cancer prevention. Approximately $70 \%$ of GPs were convinced about the effectiveness of primary cancer prevention, although they pointed to several limitations, e.g. low financial support, little knowledge and level of awareness of the patients, as well as ineffective primary prevention. A routine physical examination was the best method of cancer prevention according to $53.8 \%$ of GPs, followed by active screening by individual invitations (35.2\%). GPs underpinned the necessity of cooperation with health care professionals, foremost with nurses (89.8\%) and specialists (71\%) [15]. Another study by Stefanowicz et al. assessed the knowledge of colorectal cancer risk factors among a random sample of 200 people. In their research, only slightly more than a half of the respondents aged 50 and older ( $54 \% ; n=108$ ) proved to be aware of the opportunity to have screening tests aimed at early detection of colorectal cancer. In our study, colonoscopy as a prevention program proved to be known to $56.8 \%$ of all respondents and to as many as $79.1 \%$ of those aged 50-69 [16].

Several studies on the knowledge of breast and cervical cancer risk factors and screening programs among women have been conducted in Poland. Cichońska et al. surveyed 50 women aged 20 to 81 (of which $50 \%$ were younger than 30 years). National cancer prevention programs were well known to $46 \%$ of them, whereas in our study, this number was nearly twice larger (72.8\%). The awareness of the existence of such programs was greatest among the oldest group and lowest among the youngest respondents in our study. Similarly to our findings, television and press were pointed out by the respondents as the best information sources of national cancer prevention programs [17]. 
Major cancer screening programs are widely available in Poland and are provided free to the target groups within the national healthcare service. Unfortunately, these preventive methods are still underutilized. Despite the obvious limitation of our study, i.e. lack of the representativeness of the study population (in fact, it used the convenience sample), we managed to draw attention to an important barrier to the uptake of these preventive methods. The common belief of those studied concerning the 'lack of availability of screening tests' needs to be corrected, and relevant information should be provided to them in a better manner. Having in the mind good effectiveness of cancer screening programs and poor cancer treatment outcomes in Poland, greater participation of the target population in these activities is a must. Therefore, it seems that there is still a lot to do in this area, and undoubtedly, there is a role for GPs to play in promoting cancer prevention and encouraging their patients to undergo relevant screenings.

\section{Conclusions}

1. Television and press were the most common information sources regarding national cancer prevention programs for the study participants. These media should be considered for future campaigns promoting cancer screenings.

2. Considering that these were mostly male patients, who admitted to have ignored early warning signs of the disease, there is a need to encourage the male part of society to undertake colorectal cancer screening through the public media, especially television, radio and the press. Apart from promoting screenings among their patients, GPs should draw their attention to the early warning signs and convince them not to hesitate reporting them to doctors as soon as possible.

3. The time between cervical screening tests depended on the level of education, while a positive family history of cancer had no effect.

4. Despite the wide availability of cancer screening programs in Poland, lack of screening tests was found to be the most common reason for the delay in cancer diagnosis provided by respondents. This proves that there is and urgent need to organise adequate information campaigns for the target population.

Source of funding: This work was funded by the authors' resources. Conflict of interest: The authors declare no conflict of interests.

\section{References}

1. Ferlay J, Soerjomataram I, Ervik M, et al. GLOBOCAN 2012 v1.0, Cancer Incidence and Mortality Worldwide: IARC CancerBase No. 11 [Internet]. Lyon, France: International Agency for Research on Cancer; 2013 [cited 19.04.2017]. Available from URL: http://globocan. iarc.fr.

2. Didkowska J, Wojciechowska U. Zachorowania i zgony na nowotwory złośliwe w Polsce. Krajowy Rejestr Nowotworów [cited 19.04.2017]. Available from URL: http://onkologia.org.pl/k/epidemiologia/ (in Polish).

3. WHO. Women's health [cited 21.04.2017]. Available from URL: http://www.who.int/mediacentre/factsheets/fs334/en/.

4. De Angelis R, Sant M, Coleman MP, et al. Cancer survival in Europe 1999-2007 by country and age: results of EUROCARE-5 - a population-based study. Lancet Oncol 2014; 15(1): 23-34.

5. Allemani C, Weir HK, Carreira H, et al. Global surveillance of cancer survival 1995-2009: analysis of individual data for 25,676,887 patients from 279 population-based registries in 67 countries (CONCORD-2). Lancet 2015; 385(9972): 977-1010.

6. Schiffman M, Wentzensen N, Wacholder S, et al. Castle Human papillomavirus testing in the prevention of cervical cancer. J Nat/ Cancer Inst 2011; 103(5): 368-383.

7. WHO. Cancer. Early diagnosis [cited 27.04.2017]. Available from URL: http://who.int/cancer/prevention/diagnosis-screening/screening/en/.

8. American Cancer Society. Can colorectal polyps and cancer be found early? Why is it important to find colorectal cancer early? [cited 29.06.2017]. Available from URL: https://www.cancer.org/cancer/colon-rectal-cancer/detection-diagnosis-staging/detection.html.

9. Latkowski B, Lukas W, eds. Medycyna rodzinna. Warszawa: Wydawnictwo Lekarskie PZWL; 2005 (in Polish).

10. Wronkowski Z, Zwierko M. Miejsce i znaczenie promocji zdrowia w zwalczaniu nowotworów złośliwych. In: Karski J, ed. Promocja zdrowia. Warszawa: Wydawnictwo Ignis; 1999: 108-119 (in Polish).

11. U.S. Preventive Service Task Force. Colorectal Cancer: Screening [cited 16.04.2017]. Available from URL: https://www.uspreventiveservicestaskforce.org/Page/Document/UpdateSummaryFinal/colorectal-cancer-screening2.

12. NIK. NIK o realizacji programu zwalczania nowotworów [cited 16.04.2017]. Available from URL: https://www.nik.gov.pl/aktualnosci/ nik-o-realizacji-programu-zwalczania-nowotworow.html (in Polish).

13. Health and Social Care Information Centre. Cervical Screening Programme, England: Statistics for 2013-14. [Leeds]: HSCIC; 2014 [cited 29.04.2017]. Available from URL: http://www.hscic.gov.uk/catalogue/PUB15968.

14. Mcllfatrick S, Keeney S, McKenna $\mathrm{H}$, et al. Investigating the role of general practitioner in cancer prevention: a mixed methods study. BMC Family Practice 2013, doi: 10.1186/1471-2296-14-58.

15. Stefanowicz A, Kulik TB, Pacian J, et al. Rola placówek podstawowej opieki zdrowotnej w realizacji profilaktyki nowotworów w opinii lekarzy rodzinnych. MONZ 2013; 19(2): 168-172 (in Polish).

16. Stefanowicz A, Kulik TB, Środa M, et al. Ocena wiedzy i świadomości osób po 50. roku życia w zakresie czynników ryzyka raka jelita grubego. Fam Med Prim Care Rev 2015; 17(3): 210-214 (in Polish).

17. Cichońska M, Borek M, Krawczyk W, et al. Wiedza kobiet w zakresie zapobiegania nowotworom piersi i raka szyjki macicy. Acta Sci Acad Ostroviensis. Sect B 2012; 1: 8-21 (in Polish).

Tables: 4

Figures: 0

References: 17

Received: 01.05.2017

Revised: 12.06 .2017

Accepted: 03.07.2017
Address for correspondence:

Marta Kurczewska-Michalak, MD

Zakład Medycyny Rodzinnej UM

ul. Narutowicza 60

90-136 Łódź, Polska

Tel.: + 4842 678-72-10

E-mail: m.kurczewska@o2.pl 